\title{
Subsurface geology and aquifer system of the Nohbi Plain, central Japan
}

\author{
T. Makinouchi ${ }^{1}$ and Tokai Three-Prefecture Investigation Committee on Land Subsidence ${ }^{2}$ \\ ${ }^{1}$ Department of Environmental Science and Technology, Faculty of Science and Technology, Meijo University, \\ Nagoya, 468-8502, Japan \\ ${ }^{2}$ Chubu Geographical Survey Institute, Geospatial Information Authority of Japan, Nagoya, 460-0001, Japan
}

Correspondence to: T. Makinouchi (takmak@meijo-u.ac.jp)

Published: 12 November 2015

\begin{abstract}
The Nohbi Plain is a typical coastal plain in Japan. The subsurface of this plain consists of alternating beds of marine clays in transgressive stages and fluvial gravels in regressive stages, and forms a groundwater basin. The aquifers are represented by the gravel beds in the regressive stages.
\end{abstract}

\section{Introduction}

The Nohbi Plain, a typical coastal plain in Japan, is situated in the Pacific coast side. This plain is approximately $50 \mathrm{~km}$ long in the $\mathrm{N}-\mathrm{S}$ direction and about $35 \mathrm{~km}$ wide in the EW direction. Three major rivers, the Kiso, Nagara, and Ibi Rivers flow into this plain (Fig. 1). The subsurface geology and aquifer systems of this plain is described in this paper. Details of land subsidence in this plain are reported in other papers.

\section{Topography of the Nohbi Plain}

Three topographic features, alluvial fan, flood plain, and delta, typical of a coastal plain, extend in this plain from upstream to downstream (Fig. 1). The eastern margin of this plain is fringed with terraces (Fig. 1).

\section{Outline of the subsurface geology}

Subsurface geology of the Nohbi Plain consists of the Nan'yo, Nohbi, First Gravel, Atsuta, Second Gravel, Ama, Third Gravel, Yatomi Formations, Plio-Pleistocene Tokai Group, and Miocene marine sediments, in descending order (Figs. 2, 3, and 4).

The Holecene Nan'yo Formation is divided into three members, uppermost mud, upper sand, and lower marine clay members. The lower marine clay member was deposited in the transgressive stage of the postglacial age. The Nohbi Formation, latest Pleistocene, is composed of sand and mud beds. The First Gravel Formation is composed of riverbed gravels during the regressive stage of the last glacial age. The Atsuta Formation, late Pleistocene, consists of upper sand and lower marine clay members. The lower marine clay member was deposited during the transgressive stage in the last interglacial age.

The Second Gravel Formation is composed of riverbed gravels during the regressive stage of the glacial age before the last interglacial. The Ama and Yatomi Formations consist of alternating beds of gravel, sand, and mud (Fig. 4).

The Plio-Pleistocene Tokai Group consists of alternating beds of gravel, sand, and mud with intercalations of many volcanic ash and lignite beds, and was deposited in Lake Tokai (paleolake), a freshwater sedimentary basin. The Lake Tokai sedimentary basin covered a wide region of the present Nohbi Plain and the surrounding areas (Fig. 5). Miocene marine sediments are mainly composed of sand and mud beds deposited under the paleo-Seto Inland Sea.

Among these strata, the marine clay members of the Nan'yo and Atsuta Formations have largely shrank, and about $80 \%$ or more of the land subsidence is owing to the shrinkage of these members. 


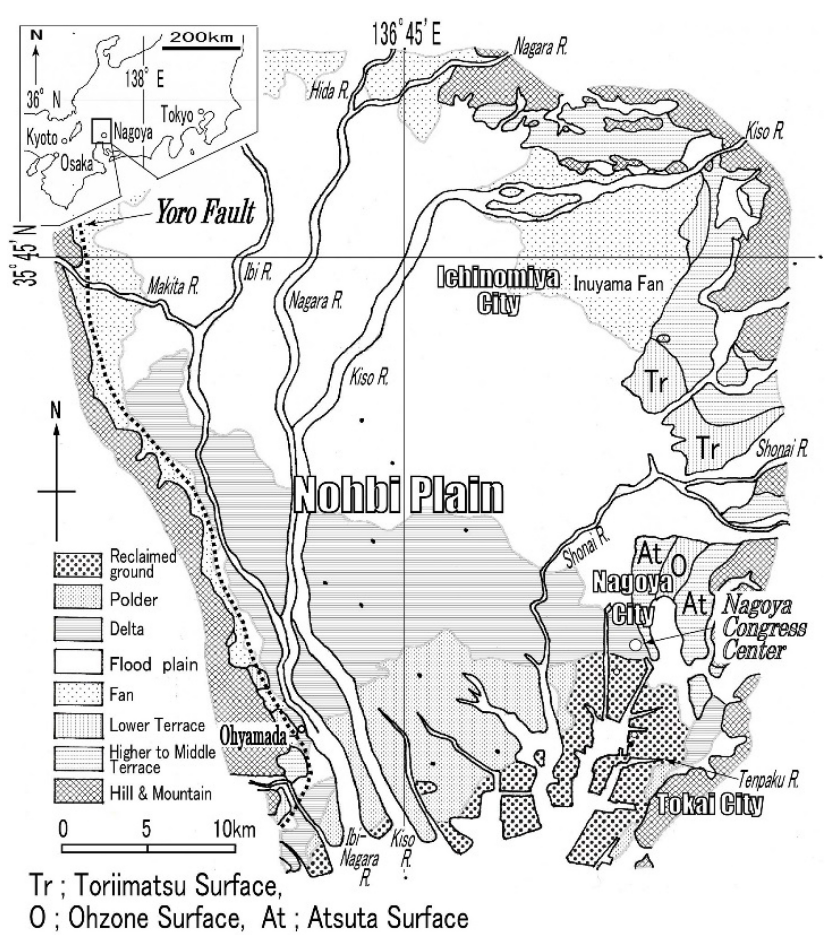

Figure 1. Topography of the Nohbi Plain (Makinouchi et al., 2013).

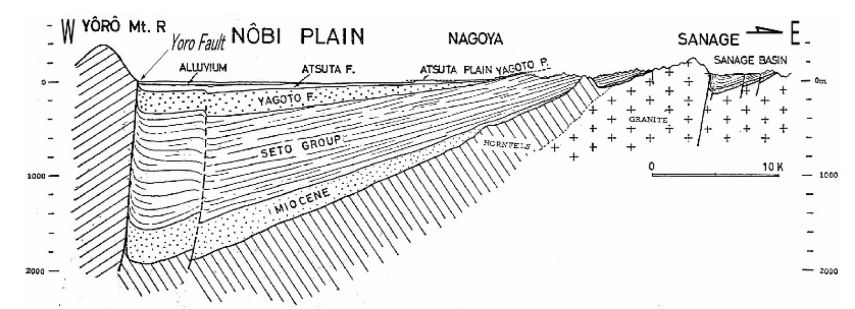

Figure 2. Quaternary block faulting and geologic profile of the Nohbi Plain (Kuwahara, 1968).

\section{Depositional process in the Nohbi Plain}

Westward tilting and glacial eustasy control the depositional process in this plain since middle Pleistocene time. The tilting forms a sedimentary basin deepened westward (Nohbi Tilting Basin, Figs. 2 and 4). The glacial eustasy influences the sedimentary facies, namely, marine facies in the transgressive stage and fluvial facies in the regressive stage.

Gradual subsidence due to tilting forms shallow depositional space, in which marine clay beds have deposited during the transgressive stages, and fluvial sand and gravel beds have deposited during the regressive stages. As the result of westward tilting and glacial eustasy, gravel, sand, and marine clay beds have alternately accumulated in this basin (Fig. 4), and many formations become thicker and deeper toward the west due to the tilting (Fig. 4).

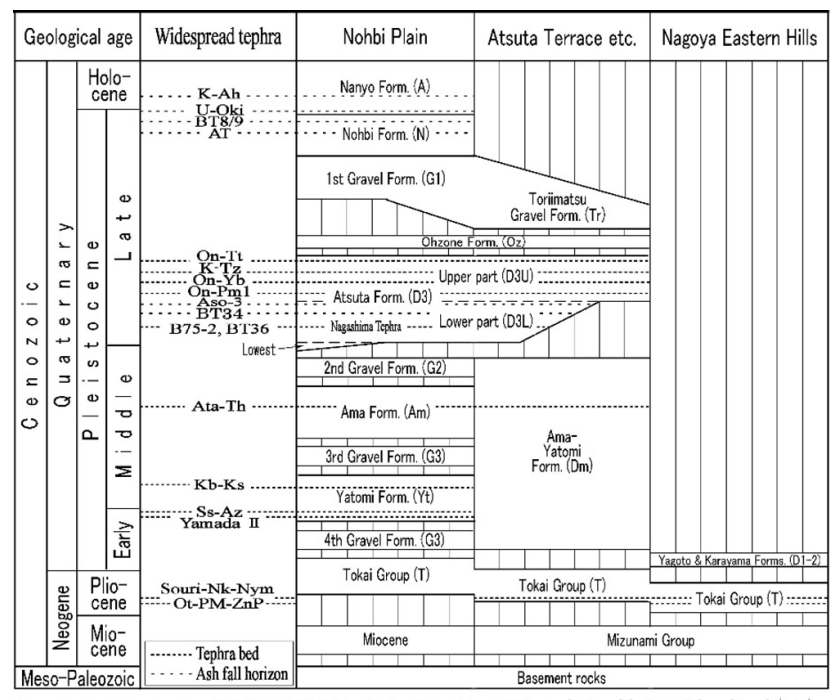

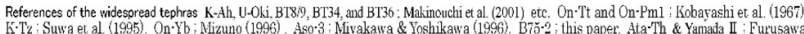

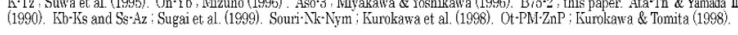

Figure 3. Subsurface stratigraphy of the Nohbi Plain and the surrounding areas (Makinouchi et al., 2013).

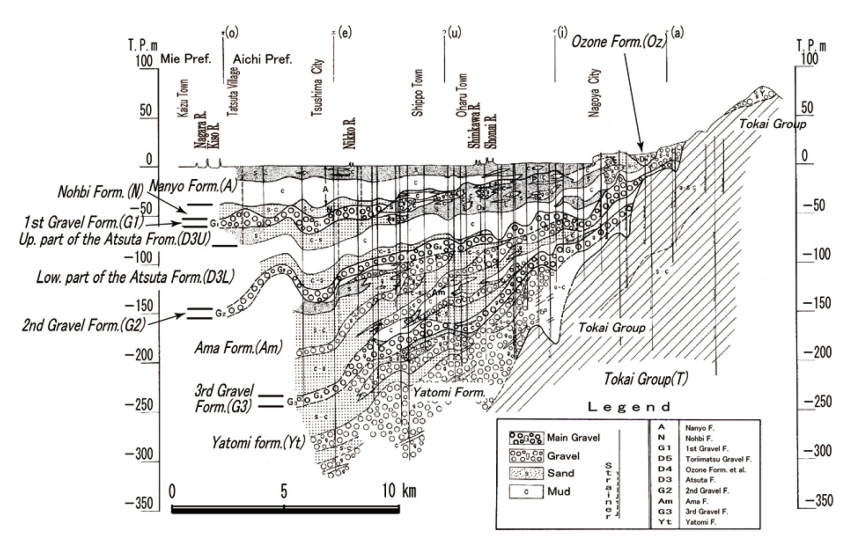

Figure 4. E-W geologic profile of the Nohbi Plain modified from Kuwahara (1985).

\section{Nohbi Groundwater Basin}

The Nohbi Groundwater Basin consists of three overlapping groundwater sub-basins (Fig. 2). The lower sub-basin is made up of Miocene marine sediments. The Miocene system yields saline water. The middle sub-basin is composed of the Plio-Pleistocene Tokai (Seto) Group. The upper sub-basin, Nohbi Basin, was formed by a block faulting which began at middle Pleistocene time (Fig. 6) and have tilted westward (Nohbi Tilting Block).

\section{Aquifer system of the Nohbi Basin}

In the Nohbi Basin, upper sand member of the Nan'yo Formation yields superficial unconfined groundwater. The base 

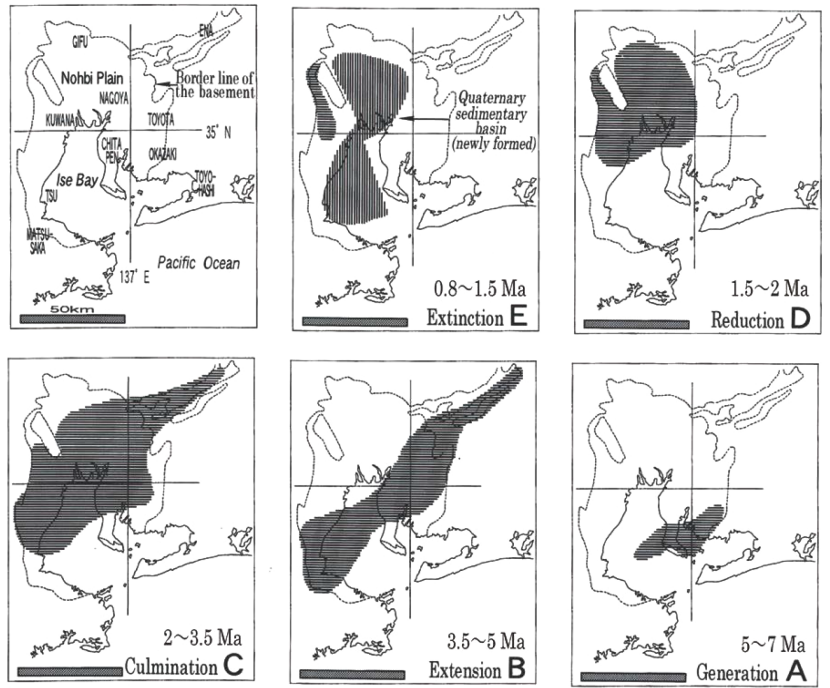

Figure 5. Change in territory (depositional area) of the Lake Tokai sedimentary basin (Makinouchi, 2001). 1 Ma: one million years ago.

depth of this member is an altitude of -30 to $-10 \mathrm{~m}$, and this member is 10 to $20 \mathrm{~m}$ thick.

Confined groundwater is abundantly supplied from fluvial gravel aquifers of the First (G1), Second (G2), and Third (G3) Gravel Formations, and also gravel beds of the Ama and Yatomi Formations. Especially, the G1 and G2 Formations are the most widely exploited ones in this basin.

The base depth of G1 Formation has an altitude of $-90 \mathrm{~m}$ (west) to $+20 \mathrm{~m}$ (east), and this formation is 10 to $30 \mathrm{~m}$ thick. The base depth of G2 Formation ranges from $-200 \mathrm{~m}$ (west) to $-10 \mathrm{~m}$ (east) in the altitude, and this formation is 10 to $20 \mathrm{~m}$ thick.

The Ama Formation and underlying sediments have many intercalations of gravel beds as aquifer units. But each aquifer unit is not easily distinguished from others, and the areal extent of a certain aquifer unit is hardly pursued. Therefore, these aquifer units are generally treated as an aquifer system in this basin.

In the middle and lower basins, the Tokai (Seto) Group and Miocene sediments yield abundant hot water.

\section{Conclusions}

Westward tilting and glacial eustasy control the depositional process in the Nohbi Basin. The tilting forms a sedimentary basin deepened westward. The glacial eustasy influences the sedimentary facies, namely, marine clays in the transgressive stages and fluvial gravels in the regressive stages. The aquifers are represented by the gravel beds in the regressive stages, and these aquifers yield abundant confined groundwater.

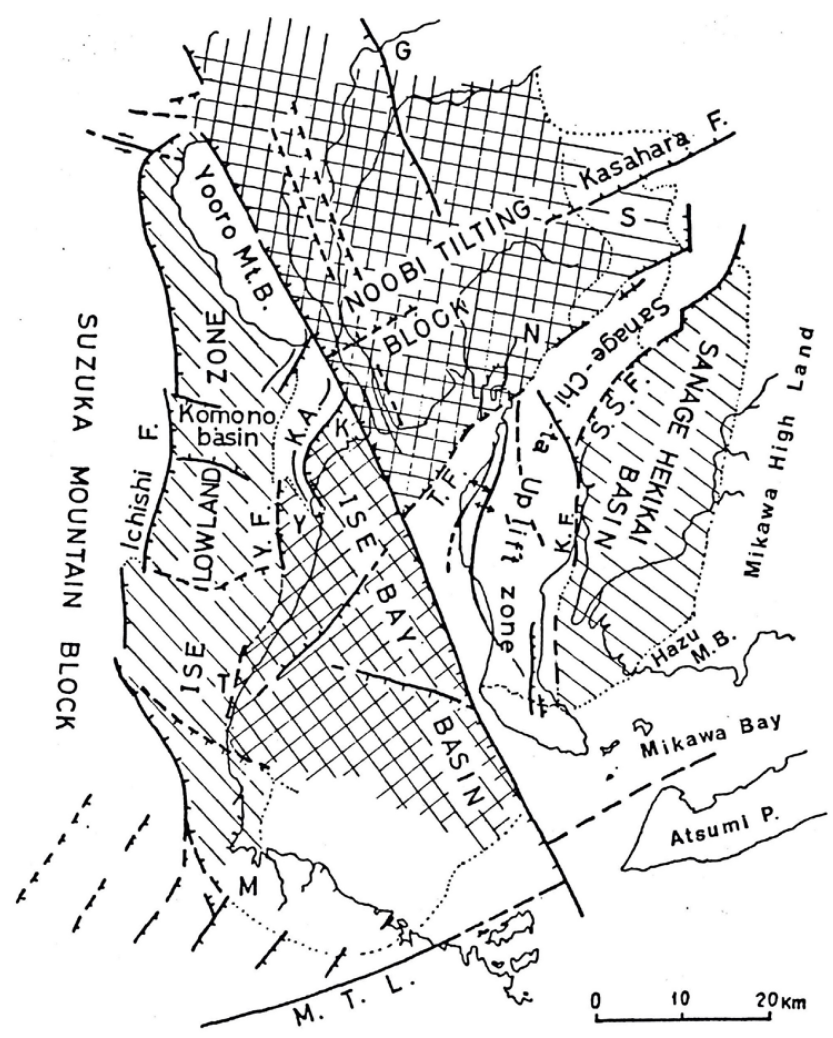

Figure 6. Quaternary block faulting in the Nohbi Plain and Ise Bay region (Kuwahara, 1969).

Acknowledgements. We express our sincere thanks to working staffs of the Tokai Three-Prefecture Investigation Committee on Land Subsidence.

\section{References}

Kuwahara, T.: The Noobi Basin and its Fault Block Movements, Quatern. Res., 7, 235-247, 1968.

Kuwahara, T.: The Ise Bay - Sedimentary Basin in the Environs of Ise Bay and Neotectonics in Southwest Japan, Symposium Kaigan Heiya (Symposium on Coastal Plain), Geological Society of Japan, Tokyo, Japan, 21-30, 1969.

Kuwahara, T.: Groundwater basin in the Nohbi Plain, Ground Subsidence and Ground Water in the Nohbi Plain, Nagoya Univ. Press, Nagoya, Japan, 35-76, 1985.

Makinouchi, T.: Stratigraphy of the Tokai Group and evolutional process of the Lake Tokai sedimentary basin, Science Report of the Toyohashi Museum of Natural History, No. 11, Toyohashi Museum of Natural History, Toyohashi, Japan, 33-39, 2001.

Makinouchi, T., Tsukamoto, M., Danhara, T., Yamashita, T., Uchizono, T., and WG of Research Committee for the Ground of Nohbi Plain: Subsurface geology in the eastern part of the Nohbi Plain, Aichi Prefecture, central Japan, J. Geol. Soc. Jpn., 119, 335-349, 2013. 